Огляди літератури, оригінальні дослідження, погляд на проблему, випадок з практики, короткі повідомлення удК 612.171.1+616.133.3/.134.9-003.93]-02:616.12-008.331.1-06:616-056.52-085.225.2

DOI 10.11603/1811-2471.2020.v.i1.10937

\title{
ДИНАМІКА ПОКАЗНИКІВ СКОРОТЛИВОЇ ФУНКЦІЇ МІОКАРДА ТА ЦЕРЕБРАЛЬНОГО КРОВОТОКУ У ХВОРИХ НА ГІПЕРТОНІЧНУ ХВОРОБУ З НАДЛИШКОВОЮ ВАГОЮ ПІСЛЯ ТЕРАПІЇ АНТИГІПЕРТЕНЗИВНИМИ ЗАСОБАМИ У ПОЄДНАННІ ЗІ СТАТИНАМИ
}

\author{
○Н. І. Петрик, І. М. Фуштей, Г. Я. Солонинка \\ ДЗ «Запорізька медична академія післядипломної освіти МОЗ України»
}

РЕЗЮМЕ. Метою роботи стало оцінити динаміку систолічної, діастолічної функції та ремоделювання лівого шлуночка міокарда, лінійних швидкостей кровотоку в басейнах загальної сонної артерії, внутрішньої сонної артерії, зовнішньої сонної артерії, середньої мозкової артерії, хребцевої артерії (V2) у хворих чоловічої і жіночої статі з гіпертонічною хворобою II стадії і надлишковою масою тіла під впливом комбінованої терапії антигіпертензивними препаратами та розувастатином.

Матеріал і методи. У 64 пацієнтів, середній вік 59.0 [48.0; 63.0] років, з гіпертонічною хворобою II стадії і надлишковою вагою оцінювали динаміку систолічної, діастолічної функції та ремоделювання лівого шлуночка, лінійних швидкостей кровотоку в басейнах загальної сонної артерії, внутрішньої сонної артерії, зовнішньої сонної артерії, середньої мозкової артерії, хребцевої артерії під впливом комбінованої терапії (фіксовані комбінації антигіпертензивних препаратів - екватор (амлодипін 5 мг та лізиноприл 10 мг) і валодіп (амлодипін 5 мг та валсартан 80 мг) впродовж 120 діб), до якої входить розувастатин 10 мг на добу.

Результати. Усім хворим було проведено загальноклінічне, лабораторне та інструментальне обстеження 3 метою верифікації діагнозу, визначення ускладнень і супутньої патології. На фоні лікування спостерігаються покращення скоротливості лівого шлуночка, його зворотне ремоделювання і збільшення потужності систолічного викиду. Показники діастолічної функції лівого шлуночка після проведеного лікування свідчать про покращення процесів його релаксації, податливості і скоротливості лівого передсердя на фоні проведеної терапії, про зменшення гіпертрофії лівого шлуночка та зниження ризику серцево-судинних ускладнень. Достовірне зменшення діаметрів обстежених мозкових артерій (ЗагСА, ВСА, ЗовнСА СМА та ХА) на фоні проведеної антигіпертензивної та протиліпідемічної терапії свідчить про зворотне структурно-функціональне ремоделювання судин головного мозку - зменшення товщини та підвищення еластичності судинної стінки.

Висновки. Покращення еластичних властивостей СМА в результаті проведеної терапії свідчить про значне зниження серцево-судинного ризику, зокрема ризику виникнення інсульту. Таким чином, спостерігається поліпшення мозкового кровообігу та трофіки головного мозку, що свідчить про адекватність і доцільність підібраної регулярної антигіпертензивної і протиліпідемічної терапії.

КЛЮчОВІ СЛОВА: систолічна функція; діастолічна функція; лінійні швидкості кровотоку; гіпертонічна хвороба; надлишкова маса тіла.

Вступ. За результатами загальнонаціонального дослідження «ндекс здоров'я. Україна - 2018» в цілому по Україні недостатню вагу мало 2,3 \% населення, нормальну $-43,5 \%$, надмірну $-36,5 \%$, а ожиріння різного ступеня - $17,7 \%$ населення [1]. Надлишок вісцеральної жирової тканини і її збільшене відношення до підшкірно-жирової клітковини, асоційовані з розвитком метаболічних порушень і артеріальної гіпертензії (АГ), з процесами серцево-судинного ремоделювання, а також ризиком серцево-судинної і загальної смертності [2-5]. Показано, що у амбулаторних пацієнтів без ознак ішемічної хвороби серця (IXC) найчастішими факторами ризику, що реєструються, $є$ АГ $(66,2 \%)$ і загальний холестерин плазми крові $>5,2$ ммоль/л (68 \%) [6]. Надлишкова вага й інсулінорезистентність (IP) сприяють зсуву ліпідного профілю, який, поряд з гіперглікемією і гіпертензією, призводить до раннього і швидкого розвитку атеросклерозу [7-12]. Отже, наявність АГ на фоні надлишкової маси тіла збільшує потенційний серцево-судинний ризик і спонукає до пошуку оптимальних терапев- тичних підходів для таких пацієнтів. Встановлено прямий зв'язок між судинним віком, індексом атерогенності і 5-річним ризиком серцево-судинних ускладнень у пацієнтів з АГ [13-15]. Показано, що у хворих вже при ожирінні I ступеня виникають порушення внутрішньосудинної динаміки, тобто ожиріння може бути незалежним фактором, що сприяє порушенню мікроциркуляції і прогресуванню ендотеліальної дисфункції [16]. Наявність атеросклеротичних бляшок навіть незначних розмірів $\epsilon$ прогностичним фактором смерті від серцево-судинних захворювань, що не залежить від результату стратифікації ризику за стандартними шкалами, зокрема, збільшує рівень ризику в 2 рази в групі помірного ризику і в 4 рази в групі низького ризику [17]. Ультразвукове дуплексне сканування магістральних судин голови та шиї за базового рівня дослідження дозволяє провести оцінку діаметрів артерій, структурних змін, дати характеристику ходу артерій, їх просвіту, оцінити стінки артерій (товщина інтима-медіа має самостійну прогностичну значимість за останніми рекомендаціями Євро- 
Огляди літератури, оригінальні дослідження, погляд на проблему, випадок з практики, короткі повідомлення пейського товариства кардіологів з діагностики і лікування АГ) $[18,19]$.

Мета - оцінити динаміку систолічної, діастолічної функції та ремоделювання лівого шлуночка міокарда, лінійних швидкостей кровотоку в басейнах загальної сонної артерії (ЗагСА), внутрішньої сонної артерії (ВCA), зовнішньої сонної артерії (ЗСА), середньої мозкової артерії (СМА), хребцевої артерії (V2) (XA) у хворих чоловічої і жіночої статі (45-65 років) з гіпертонічною хворобою II стадії і надлишковою масою тіла під впливом комбінованої терапії антигіпертензивними препаратами та розувастатином.

Матеріал і методи дослідження. Обстежено 64 пацієнти (середній вік 59,0 [48,0; 63,0] років) з гіпертонічною хворобою (ГХ) ІІ стадії і надлишковою вагою, що перебували на стаціонарному лікуванні. Усі обстежені були зіставні за віком і соціальним статусом.

Критерії включення в дослідження: пацієнти чоловічої і жіночої статі (45-65 років); гіпертонічна хвороба II стадії, діагностована за Рекомендаціями ESH (European Society of Hypertension - $\epsilon_{\text {B- }}$ ропейська спілка гіпертензії) / ESC (Euгореап Society of Cardiology - Європейська спілка кардіологіï) [18], ризик 2-4; пацієнти з порушеною толерантністю до вуглеводів, підтвердженою біохімічними методами; надмірна маса тіла (IMT понад 25-30 кг/м²); відома тривалість захворювання більше 3 років.

Критерії виключення з дослідження: порушення серцевого ритму за типом постійної форми фібриляції передсердя, шлуночкові екстрасистоли вище 2 класу за B. Lown; IXC, гострий інфаркт міокарда, прогресуюча стенокардія; CH більше II класу за NYHA (New York Heart Association Functional Classification) (Ila за Стражеско М. Д. і Василенко В. Х.); бронхіальна астма; кардіоміопатії, міокардит; декомпенсовані вади серця; порушення функції щитоподібної залози; гострі запальні або загострення хронічних запальних захворювань; алкогольна залежність, наркоманія, наявність психічних захворювань; хронічна ниркова недостатність; порушення функції печінки; відмова пацієнта продовжувати участь у дослідженні.

Дослідження проводилось відповідно до вимог Гельсінської декларації прав людини (1964), Конференції з гармонізації належної клінічної практики (GSP - ICH), Конвенції Ради Європи про захист прав і честі людини у зв'язку з використанням досягнень біології і медицини. Усі обстежувані підписали інформовану згоду для участі в дослідженні згідно з протоколом, затвердженим комісією з біоетики ДЗ «Запорізька медична академія післядипломної освіти МОЗ України».

Усім хворим було проведено загальноклінічне, лабораторне і інструментальне обстеження з метою верифікації діагнозу, визначення ускладнень і супутньої патології.

Оцінка параметрів внутрішньосерцевої гемодинаміки проводилася на початку дослідження та після 120 днів лікування за допомогою ехокардіографії на апараті Sonoline G - 60s («SIEMENS»). ЕхоКГ проводилася за методикою та стандартним протоколом дослідження хворих з ГХ у М- і В-режимах ехолокації з парастернальної і апікальної позицій датчиком 2,5 MHz.

ММлШ аналізували окремо у жінок у чоловіків, використовуючи гендерні норми ІММлШ для діагностики гіпертрофії лівого шлуночка (ГЛШ):

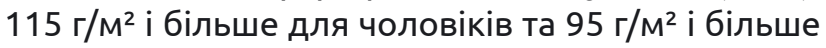
для жінок. Для визначення типу ремоделювання лівого шлуночка (ЛШ) використовували класифікацію A. Ganau et al.: нормальна модель лШ (при ІММЛШ $\leq 115$ г/м² і ВТС ЛШ <0,42), концентричне ремоделювання ЛШ (при ІММЛШ $\leq 115$ г/м² і ВТС ЛШ $\geq 0,42)$, ексцентрична гіпертрофія ЛШ (при ІММЛШ $\geq 115$ г/м² і ВТС ЛШ <0,42), концентрична

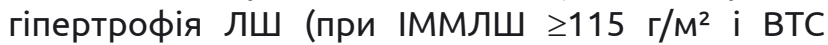
лш $\geq 0,42)$.

Показники трансмітрального кровотоку діастоли лівого шлуночка серця оцінювали за допомогою імпульсно-хвильової доплерографії. Визначали максимальну швидкість раннього діастолічного наповнення лівого шлуночка (Е), максимальну швидкість кровотоку у систолу передсердь (А), відношення максимальних швидкостей кровотоку (E/A), час уповільнення потоку в період раннього діастолічного наповнення (DT), час ізоволемічного розслаблення (IVRT).

Для ультразвукового дуплексного сканування (УзДС) судин голови та шиї використовували доплерограф Toshibo Aplio 300 (Японія). При проведенні УЗДС магістральних артерій, а саме загальної сонної артерії (ЗагСА), внутрішньої сонної артерії (ВCA), зовнішньої сонної артерії (ЗовнСА) та хребтової артерії (XA), оцінювали діаметр магістральних судин (d), пікову систолічну швидкість кровотоку (Vps), кінцеву діастолічну швидкість кровотоку (Ved), усереднену за часом максимальну швидкість кровотоку (ТАMX), індекс пульсації (Gosling) (PI), індекс резистивності (RI), систоло-діастолічний коефіцієнт (СДК) Stuart. Усі виміри проводились в однойменних артеріях праворуч та ліворуч, потім вираховувалося середнє значення.

Пацієнти були рандомізовано поділені на дві підгрупи, які приймали фіксовані комбінації антигіпертензивних препаратів впродовж 120 діб. Пацієнтам першої підгрупи був призначений комбінований препарат екватор («Гедеон Ріхтер», Угорщина) в початковій дозі 1 таблетка (амлодипін 
Огляди літератури, оригінальні дослідження, погляд на проблему, випадок з практики, короткі повідомлення 5 мг та лізиноприл 10 мг) на добу, другої підгрупи - валодіп (KRKA, Словенія) в початковій дозі 1 таблетка (амлодипін 5 мг та валсартан 80 мг) на добу. Впродовж двох тижнів проводили, за необхідності, корекцію доз препаратів. Корекції дози препарату не потребували 10 (31,3 \%) пацієнтів 3 першої підгрупи та 13 (40,6 \%) осіб другої. Іншим пацієнтам були збільшені дози препаратів екватор в дозуванні (амлодипін 5 мг та лізиноприл 20 мг) 1 таблетка на добу або валодіп (амлодипін 5 мг та валсартан 160 мг) 1 таблетка на добу, відповідно. Цільовий рівень АТ (130/85 мм рт. ст.) був досягнутий у 24 (75.0 \%) пацієнтів у першій підгрупі і в 26 (81.3 \%) пацієнтів у другій підгрупі. Усім пацієнтам був призначений розувастатин (Роксера, KRKA) в дозі 10 мг на добу.

Отримані дані були представлені у вигляді медіани та міжквартильного діапазону Ме [Q25; Q75]. Проводили аналіз розподілу за кожним вивченим критерієм. Результати дослідження аналізували за допомогою методів параметричної або непараметричної статистики залежно від типового розподілу з використанням спеціалізованих комп'ютерних програм AраcheOpenOffice (версія 4.1) і PSPP

(версія 0.10.2). При перевірці статистичних гіпотез нульову гіпотезу відкидали при рівні статистичної значущості (р) нижче 0,05. При порівнянні більше двох незалежних змінних використовували дисперсійний аналіз (One-way ANOVA) з наступними емпіричними тестами. Рівність відмінностей тестували за допомогою тесту Leuven. У випадку рівності відмінностей у групах використовували критерій Шеффе, а у випадку відсутності рівності відмінностей зверталися до тесту Т2-Tamhein. У випадку розподілу даних, відмінного від нормального, використовували аналог дисперсійного аналізу методом Kruskal-Wallis з наступним post-hoc аналізом 3 використанням критерію Dunn.

Результати й обговорення. Показники внутрішньосерцевої гемодинаміки (лінійний розмір ЛП, КДО, КСО, ФВ, ММЛШ та ІММЛШ) на початку лікування достовірно $(p>0,05)$ не відрізнялись у підгрупах хворих на ГХ ІІ стадії з надлишковою вагою (табл. 1), що свідчить про однорідність вибірок пацієнтів. Лінійний розмір лівого передсердя достовірно $(p<0,05)$ зменшився в обох підгрупах після 120 днів проведеної комбінованої терапії на $(2,8 \pm 0,12) \%$ і $(3,06 \pm 0,1)$ \% відповідно. Достовірної різниці між

Таблиця 1. Показники систолічної функції та ремоделювання лівого шлуночка у хворих на ГХ ІІ стадії з надлишковою вагою при комбінованій терапії (Me [25; 75], n=64)

\begin{tabular}{|c|c|c|c|c|}
\hline $\begin{array}{c}\text { Показник, одиниця } \\
\text { вимірювання }\end{array}$ & $\begin{array}{c}\text { Підгрупи } \\
\text { терапії }\end{array}$ & До лікування & Через 120 днів & $\Delta \%$ \\
\hline 1 & 2 & 3 & 4 & 5 \\
\hline \multirow[t]{3}{*}{ ЛП, см } & $(n=32)$ & $\begin{array}{c}4,05[3,75 ; 4,30] \\
P_{3-4}=0,0001\end{array}$ & $3,92[3,69 ; 4,18]^{*}$ & $-3,02[-3,45 ;-2,24]$ \\
\hline & $(n=32)$ & $\begin{array}{c}4,10[3,70 ; 4,60] \\
P_{3-4}=0,0001\end{array}$ & $3,95[3,61 ; 4,47]^{*}$ & $-3,08[-3,36 ;-2,73]$ \\
\hline & р-рівень & $p=0,21$ & $p=0,25$ & $p=0,31$ \\
\hline \multirow[t]{3}{*}{ КДО, мл } & $(n=32)$ & $\begin{array}{c}104,94[85,37 ; 136,27] \\
\mathrm{P}_{3-4}=0,0001\end{array}$ & $99,94[81,97 ; 130,34]$ & $-4,19[-4,50 ;-3,70]$ \\
\hline & $(n=32)$ & $\begin{array}{c}102,36[87,68 ; 129,71] \\
P_{3-4}=0,0001\end{array}$ & $99,50[84,81 ; 122,50]$ & $-4,14[-4,83 ;-3,50]$ \\
\hline & р-рівень & $\mathrm{p}=0,97$ & $p=0,95$ & $p=0,39$ \\
\hline \multirow[t]{3}{*}{$\mathrm{KCO}$, мл } & $(n=32)$ & $\begin{array}{c}37,91[32,21 ; 51,51] \\
P_{3-4}=0,0001\end{array}$ & $30,94[26,69 ; 43,41]^{*}$ & $-22,93[-29,41 ;-19,40]$ \\
\hline & $(n=32)$ & $\begin{array}{c}39,73[33,61 ; 49,15] \\
P_{3-4}=0,0001\end{array}$ & $30,15[24,89 ; 39,16]^{*}$ & $-30,15[-37,21 ;-26,98]$ \\
\hline & р-рівень & $p=0,72$ & $p=0,57$ & $p=0,02$ \\
\hline \multirow[t]{3}{*}{$\Phi B, \%$} & $(n=30)$ & $\begin{array}{c}61,22[56,46 ; 64,30] \\
P_{3-4}=0,0001\end{array}$ & $66,14[62,63 ; 74,17]$ * & $8,77[7,65 ; 10,42]$ \\
\hline & $(n=32)$ & $\begin{array}{c}62,16[58,31 ; 65,78] \\
P_{3-4}=0,0001\end{array}$ & $69,05[65,60 ; 73,97]$ & $11,32[10,40 ; 12,58]$ \\
\hline & p-рівень & $\mathrm{p}=0,66$ & $p=0,16$ & $p=0,0004$ \\
\hline \multirow[t]{3}{*}{ ММЛШ, г } & $(n=32)$ & $\begin{array}{c}221,44[196,05 ; 254,20] \\
P_{3-4}=0,0001\end{array}$ & $207,74[182,35 ; 240,50]$ & $-6,59[-7,51 ;-5,72]$ \\
\hline & $(n=32)$ & $\begin{array}{c}238,13[182,62 ; 276,01] \\
P_{3-4}=0,0001\end{array}$ & $\begin{array}{c}224,03[168,52 ; \\
261,91]\end{array}$ & $-6,30[-8,37 ;-5,38]$ \\
\hline & р-рівень & $\mathrm{p}=0,48$ & $p=0,51$ & $p=0,91$ \\
\hline
\end{tabular}


Огляди літератури, оригінальні дослідження, погляд на проблему, випадок з практики, короткі повідомлення

Продовження табл. 1

\begin{tabular}{|c|c|c|c|c|}
\hline 1 & 2 & 3 & 4 & 5 \\
\hline \multirow[t]{3}{*}{ IMМЛШ, г/M² } & $(n=32)$ & $\begin{array}{c}118,02[100,06 ; 135,19] \\
P_{3-4}=0,0001\end{array}$ & $109,72[91,76 ; 126,89]$ & $-7,57[-9,05 ;-6,54]$ \\
\hline & $(n=32)$ & $\begin{array}{c}126,82[90,41 ; 149,62] \\
P_{3-4}=0,0001\end{array}$ & $116,80[80,39 ; 139,60]$ & $-8,60[-12,47 ;-7,18]$ \\
\hline & p-рівень & $p=0,72$ & $\mathrm{p}=0,85$ & $p=0,42$ \\
\hline
\end{tabular}

Примітки (тут і далі): * - при p<0,05; ** - при p<0,01; *** - при p<0,001 - достовірна відмінність після проведеної терапії.

цим розміром у підгрупах після лікування не виявлено. Показники систолічної функції (КДО та КСО) достовірно $(p<0,05)$ зменшилися на фоні проведеної терапії у обох підгрупах: у першій підгрупі КДО зменшився на $(4,22 \pm 0,13) \%$, а КСО на $(25,06 \pm 1,69)$, у другій підгрупі КДО і КСО зменшилися на $(4,12 \pm 0,19) \%$ і $(33,44 \pm 2,03)$ \% відповідно. Між підгрупами достовірної різниці за цими показниками після лікування також не виявлено. Фракція викиду ЛШ на фоні проведеної комбінованої терапії достовірно $(p<0,05)$ збільшилась в обох підгрупах (на $(9,17 \pm 0,40) \%$ і $(11,57 \pm 0,27) \%$ відповідно), тобто показники ФВ як до, так і після лікування, знаходилися в межах норми, що свідчить про збереження скоротливості ЛШ. Терапія також привела до достовірного $(p<0,05)$ зниження як ММЛШ (на $(6,77 \pm 0,35) \%$ і $(6,93 \pm 0,39) \%$ у обох підгрупах відповідно), так i ІММЛШ (на $(7,83 \pm 0,41) \%$ і $(9,65 \pm 0,53) \%$ у підгрупах відповідно), що свідчить про зворотне ремоделювання ЛШ на фоні проведеної терапії.

Показники діастолічної функції лівого шлуночка у хворих на ГX II стадії з надлишковою вагою були зіставні між обома підгрупами $(p>0,05)$ до початку лікування (табл. 2). Після проведеного комбі- нованого лікування в обох підгрупах відмічалося достовірне $(p<0,05)$ підвищення співвідношення максимальної швидкості раннього діастолічного наповнення до максимальної швидкості кровотоку у систолу передсердь (E/A) - на $(14,32 \pm 1,49) \%$ i $(18,75 \pm 1,93)$ \% відповідно, що свідчить про покращення процесів релаксації ЛШ, податливості лШ і скоротливості лП. Таке покращення на фоні проведеної терапії також підтверджується і достовірним $(p<0,05)$ зниженням показника часу уповільнення раннього діастолічного наповнення (DT) на (13,35 $0,63) \%$ і $(26,98 \pm 0,59)$ у підгрупах відповідно, а також часу ізоволюмічного розслаблення (IVRT) на $(13,23 \pm 0,65) \%$ і $(15,69 \pm 0,75) \%$ в підгрупах відповідно. Привертає увагу наявність достовірної $(p<0,05)$ різниці в показниках DT між першою та другою підгрупами після проведення комбінованої терапії, що свідчить про переваги комбінованої терапії з використанням сартанів, які здійснюють більш помітний вплив на процес релаксації ЛШ, діастолічний тиск у ЛШ після відкриття мітрального клапана і податливість ЛШ.

Аналіз показників лінійних швидкостей кровотоку в басейнах загальної сонної артерії (ЗагСА),

Таблиця 2. Показники діастолічної функції серця у хворих на ГX II стадії при комбінованій терапії (Me $[25 ; 75], n=64)$

\begin{tabular}{|c|c|c|c|c|}
\hline $\begin{array}{c}\text { Показник, одиниця } \\
\text { вимірювання }\end{array}$ & $\begin{array}{l}\text { Підгрупи } \\
\text { терапії }\end{array}$ & До лікування & Через 120 днів & $\Delta \%$ \\
\hline \multirow[t]{3}{*}{$E / A$} & $(n=32)$ & $\begin{array}{c}1,26[0,84 ; 1,58] \\
P_{3-4}=0,0001\end{array}$ & $1,47[1,02 ; 1,72]^{*}$ & $12,70[8,15 ; 18,45]^{*}$ \\
\hline & $(n=32)$ & $\begin{array}{c}1,26[0,84 ; 1,58] \\
P_{3-4}=0,0001\end{array}$ & $1,57[1,14 ; 1,75]^{*}$ & $20,32[7,24 ; 26,96]^{*}$ \\
\hline & р-рівень & $p=0,785$ & $p=0,69$ & $p=0,16$ \\
\hline \multirow[t]{3}{*}{ DT, MC } & $(n=32)$ & $\begin{array}{c}185,00[168,50 ; 249,50] \\
P_{3-4}=0,0001\end{array}$ & $167,00[150,00 ; 212,00]$ * & $-13,57[-15,07 ;-10,55]^{*}$ \\
\hline & $(n=32)$ & $\begin{array}{c}179,00[168,00 ; 244,00] \\
P_{3-4}=0,0001\end{array}$ & $144,00[131,00 ; 190,00]$ & $-26,71[-29,29 ;-25,84]^{*}$ \\
\hline & р-рівень & $p=0,91$ & $p=0,039$ & $p=0,0001$ \\
\hline \multirow[t]{3}{*}{ IVRT, MC } & $(n=32)$ & $\begin{array}{c}87,00[76,50 ; 117,00] \\
P_{3-4}=0,0001\end{array}$ & $74,50[68,00 ; 101,00]^{*}$ & $-13,62[-14,94 ;-11,69]^{*}$ \\
\hline & $(n=32)$ & $\begin{array}{c}91,00[77,50 ; 113,50] \\
P_{3-4}=0,0001\end{array}$ & $79,00[68,00 ; 98,00]^{*}$ & $-16,87[-18,66 ;-13,92]^{*}$ \\
\hline & р-рівень & $p=0,69$ & $p=0,54$ & $p=0,09$ \\
\hline
\end{tabular}


Огляди літератури, оригінальні дослідження, погляд на проблему, випадок з практики, короткі повідомлення внутрішньої сонної артерії (ВCA), зовнішньої сонної артерії (3СA), середньої мозкової артерії (СМА), хребцевої артерії (V2) (XA) на фоні проведеної комбінованої терапії впродовж 120 днів показав, що в басейні ЗагСА достовірних відмінностей між показниками в двох підгрупах до початку лікування не було (табл. 3). Після 120 днів комбінованої терапії у обох підгрупах діаметр ЗагСА достовірно $(p<0,05)$ зменшився на $(0,60 \pm 0,16) \%$ і $(1,76 \pm 0,21) \%$ відповідно. Про поліпшення кровотоку в басейні ЗагСА свідчать також збільшення показника пікової систолічної швидкості кровотоку (Vps) на $(5,61 \pm 0,21) \%$ і $(4,38 \pm 0,13)$ \% і кінцевої діастолічної швидкості кровотоку (Ved) на $(6,16 \pm 0,19)$ \% і $(6,18 \pm 0,21)$ \% в обох підгрупах відповідно. Усереднена за часом максимальна швидкість кровотоку (TAMX) на фоні проведеної комбінованої антигіпертензивної та протиліпідемічної терапії достовірно ( $<<0,05)$ знизилась на $(2,25 \pm 0,17) \%$ і $(5,12 \pm 0,49) \%$, демонструючи зниження рівня периферійного опору. Індекс резистентності (RI) також достовірно ( $<<0,05)$ знизився на $(5,58 \pm 0,32) \%$ і $(6,97 \pm 0,25)$ \% в обох підгрупах. Індекс пульсації (PI) достовірно підвищився $(p<0,05)$ під впливом комбінованої терапії на $(7,52 \pm 0,31) \%$ і $(9,27 \pm 1,20) \%$ в обох підгрупах відповідно, що свідчить про поліпшення еластичних властивостей артерій і зменшення циркуляторного опору. Систоло-діастолічний коефіцієнт (s/d) після проведеної

Таблиця 3. Показники лінійних швидкостей кровотоку в басейні загальної сонної артерії у хворих на ГX II стадії з надлишковою вагою при комбінованій терапії (Me [25; 75], n=64)

\begin{tabular}{|c|c|c|c|c|}
\hline $\begin{array}{c}\text { Показник, одиниця } \\
\text { вимірювання }\end{array}$ & $\begin{array}{l}\text { Підгрупи } \\
\text { терапії }\end{array}$ & До лікування & Через 120 днів & $\Delta \%$ \\
\hline \multirow[t]{3}{*}{$D, M M$} & $(n=32)$ & $\begin{array}{c}6,10[5,35 ; 6,68] \\
p_{3-4}=0,0001\end{array}$ & $6,07[5,34 ; 6,60]^{*}$ & $-0,53[-0,71 ;-0,31]$ \\
\hline & $(n=32)$ & $\begin{array}{c}5,95[5,40 ; 6,28] \\
\mathrm{P}_{3-4}=0,0001\end{array}$ & $5,84[5,30 ; 6,20]$ & $-1,59[-1,96 ;-0,96]$ \\
\hline & р-рівень & $p=0,745$ & $p=0,47$ & $p=0,0001$ \\
\hline \multirow[t]{3}{*}{ Vps, cm/c } & $(n=32)$ & $\begin{array}{c}75,78[65,48 ; 81,08] \\
P_{3-4}=0,0001\end{array}$ & $80,95[69,40 ; 86,00]$ & $5,84[5,42 ; 6,13]$ \\
\hline & $(n=32)$ & $\begin{array}{c}76,08[59,80 ; 87,53] \\
\mathrm{P}_{3-4}=0,0001\end{array}$ & $79,34[63,04 ; 91,13]$ & $4,34[3,90 ; 4,13]$ \\
\hline & р-рівень & $p=0,62$ & $p=0,86$ & $p=0,0001$ \\
\hline \multirow[t]{3}{*}{ Ved,cm/c } & $(n=32)$ & $\begin{array}{c}18,43[15,23 ; 22,53] \\
P_{3-4}=0,0001\end{array}$ & $19,60[16,25 ; 24,00]^{* *}$ & $6,17[5,67 ; 6,86]$ \\
\hline & $(n=32)$ & $\begin{array}{c}20,05[15,43 ; 25,80] \\
P_{3-4}=0,0001\end{array}$ & $21,53[16,36 ; 27,50]^{*}$ & $6,08[5,28 ; 6,97]$ \\
\hline & P-рівень & $p=0,17$ & $p=0,16$ & $p=0,3948$ \\
\hline \multirow[t]{3}{*}{ TAMX, cM/c } & $(n=32)$ & $\begin{array}{c}31,95[25,88 ; 39,33] \\
P_{3-4}=0,0001\end{array}$ & $30,97[25,57 ; 38,55]^{* * *}$ & $-2,19[-3,02 ;-1,49]$ \\
\hline & $(n=32)$ & $\begin{array}{c}35,08[27,30 ; 39,60] \\
P_{3-4}=0,0001\end{array}$ & $32,75[26,35 ; 37,40]$ & $-4,61[-6,47 ;-3,25]$ \\
\hline & р-рівень & $p=0,30$ & $p=0,49$ & $p=0,0001$ \\
\hline \multirow[t]{3}{*}{ RI } & $(n=32)$ & $\begin{array}{c}0,74[0,72 ; 0,80] \\
p_{3-4}=0,0001\end{array}$ & $0,71[0,67 ; 0,77]$ & $-5,67[-6,37 ;-5,11]$ \\
\hline & $(n=32)$ & $\begin{array}{c}0,74[0,71 ; 0,78] \\
P_{3-4}=0,0001\end{array}$ & $0,70[0,66 ; 0,73]$ & $-6,87[-7,79 ;-6,00]$ \\
\hline & р-рівень & $p=0,51$ & $p=0,23$ & $p=0,0001$ \\
\hline \multirow[t]{3}{*}{$\mathrm{PI}$} & $(n=32)$ & $\begin{array}{c}1,66[1,37 ; 1,98] \\
P_{3-4}=0,0001\end{array}$ & $1,80[1,49 ; 2,18]$ & $7,77[6,98 ; 8,82]$ \\
\hline & $(n=32)$ & $\begin{array}{c}1,60[1,36 ; 1,80] \\
P_{3-4}=0,0001\end{array}$ & $1,77[1,54 ; 2,04]$ & $8,79[6,65 ; 10,08]$ \\
\hline & р-рівень & $p=0,18$ & $p=0,32$ & $\mathrm{p}=0,42$ \\
\hline \multirow[t]{3}{*}{$s / d$} & $(n=32)$ & $\begin{array}{c}3,89[3,53 ; 4,79] \\
p_{3-4}=0,036\end{array}$ & $3,89[3,47 ; 4,73]$ & $0,29[1,58 ; 0,32]$ \\
\hline & $(n=32)$ & $\begin{array}{c}3,65[3,12 ; 4,59] \\
P_{3-4}=0,0004\end{array}$ & $3,56[3,06 ; 4,30]$ & $-1,67[-2,33 ;-0,67]$ \\
\hline & р-рівень & $p=0,22$ & $p=0,16$ & $p=0,01$ \\
\hline
\end{tabular}


Огляди літератури, оригінальні дослідження, погляд на проблему, випадок з практики, короткі повідомлення комбінованої терапії достовірно (р<0,05) знизився на $(0,59 \pm 0,24) \%$ і $(1,42 \pm 0,42) \%$ відповідно у двох підгрупах. Привертає увагу, що достовірно $(p<0,05)$ більш виражене зниження діаметра ЗагСА, ТАМХ, RI, коефіцієнта s/d і достовірно (p<0,05) більш виражене підвищення показника Vps спостерігалося в другій підгрупі пацієнтів, яких лікували з використанням сартанів, що свідчить про кращий вплив цієї схеми антигіпертензивних засобів на покращення мозгового кровотоку.

Лінійні показники кровотоку в басейні внутрішньої сонної артерії (ВСА) у хворих на ГХ ІІ стадії 3 надлишковою вагою першої та другої підгруп (табл. 4) також, як і в басейні ЗагСА, не мали достовірних відмінностей до початку лікування. На фоні комбінованої терапії діаметр ВСА достовірно $(p<0,05)$ зменшився на $(0,58 \pm 0,08) \%$ i $(4,05 \pm 0,48) \%$ в обох підгрупах відповідно. Показники Vps, Ved i TAMX достовірно $(p<0,05)$ підвищилися: Vps на $(10,84 \pm 0,23) \%$ і $(6,14 \pm 0,23) \%$, Ved на $(12,90 \pm 0,76) \%$ і $(11,40 \pm 0,32) \%$, TAMX на $(5,43 \pm 0,56) \%$ і $(1,63 \pm 0,22) \%$ у обох підгрупах відповідно. Натомість RI на фоні проведеної терапії достовірно $(p<0,05)$ зменшився на $(7,10 \pm 0,34) \%$ і $(7,88 \pm 0,45) \%$, а РІ достовірно $(p<0,05)$ підвищився на $(4,77 \pm 0,56) \%$ i $(1,61 \pm 0,31) \%$ у обох підгрупах відповідно. Співвідношення s/d достовірно $(p<0,05)$ знизилось на $(2,72 \pm 1,00) \%$ i $(5,77 \pm 0,49)$ \% у обох підгрупах відповідно, що свід-

Таблиця 4. Показники лінійних швидкостей кровотоку в басейні внутрішньої сонної артерії у хворих на ГX II стадії з надлишковою вагою при комбінованій терапії (Me [25; 75], n=64)

\begin{tabular}{|c|c|c|c|c|}
\hline $\begin{array}{c}\text { Показник, одини- } \\
\text { ця вимірювання }\end{array}$ & $\begin{array}{c}\text { Підгрупи } \\
\text { терапії }\end{array}$ & До лікування & Через 120 днів & $\Delta \%$ \\
\hline \multirow[t]{3}{*}{$\mathrm{d}, \mathrm{mM}$} & $(n=32)$ & $\begin{array}{c}4,45[4,25 ; 4,65] \\
P_{3-4}=0,0001\end{array}$ & $4,44[4,23 ; 4,64]^{*}$ & $-0,47[-0,67 ;-0,33]$ \\
\hline & $(n=32)$ & $\begin{array}{c}4,45[4,25 ; 4,68] \\
p_{3-4}=0,0001\end{array}$ & $4,25[4,13 ; 4,52]^{*}$ & $-3,49[-5,22 ;-2,25]$ \\
\hline & р-рівень & $p=0,93$ & $p=0,035$ & $p=0,0001$ \\
\hline \multirow[t]{3}{*}{ Vps, cm/c } & $(n=32)$ & $\begin{array}{c}47,28[42,10 ; 62,70] \\
P_{3-4}=0,0001\end{array}$ & $53,05[47,51 ; 69,05]^{*}$ & $10,70[9,95 ; 11,64]^{*}$ \\
\hline & $(n=32)$ & $\begin{array}{c}52,10[38,48 ; 62,85] \\
P_{3-4}=0,0001\end{array}$ & $55,68[41,21 ; 66,88]$ & $6,12[5,55 ; 6,74]^{*}$ \\
\hline & р-рівень & $p=0,87$ & $p=0,90$ & $p=0,0001$ \\
\hline \multirow[t]{3}{*}{ Ved, cm/c } & $(n=32)$ & $\begin{array}{c}16,48[13,93 ; 21,00] \\
P_{3-4}=0,0001\end{array}$ & $18,96[16,15 ; 24,00]^{*}$ & $12,79[10,64 ; 13,52]^{*}$ \\
\hline & $(n=32)$ & $\begin{array}{c}16,23[12,43 ; 23,55] \\
P_{3-4}=0,0001\end{array}$ & $18,48[14,17 ; 26,31]^{*}$ & $11,12[10,13 ; 12,70]^{*}$ \\
\hline & р-рівень & $p=0,70$ & $p=0,814$ & $p=0,0489$ \\
\hline \multirow[t]{3}{*}{ TAMX, cM/c } & $(n=32)$ & $\begin{array}{c}26,43[22,95 ; 28,90] \\
P_{3-4}=0,0001\end{array}$ & $28,30[24,15 ; 30,65]^{* *}$ & $4,70[3,48 ; 6,97]^{*}$ \\
\hline & $(n=32)$ & $\begin{array}{c}25,40[21,30 ; 34,73] \\
P_{3-4}=0,0001\end{array}$ & $25,80[21,62 ; 35,75]$ & $1,64[0,48 ; 2,44]^{*}$ \\
\hline & р-рівень & $p=0,85$ & $p=0,51$ & $p=0,0001$ \\
\hline \multirow[t]{3}{*}{$\mathrm{RI}$} & $(n=32)$ & $\begin{array}{c}0,67[0,61 ; 0,71] \\
P_{3-4}=0,0001\end{array}$ & $0,62[0,57 ; 0,66]$ & $-6,43[-7,41 ;-6,06]$ \\
\hline & $(n=32)$ & $\begin{array}{c}0,67[0,60 ; 0,72] \\
P_{3-4}=0,0001\end{array}$ & $0,62[0,56 ; 0,67]$ & $-7,73[-9,63 ;-6,41]$ \\
\hline & р-рівень & $p=0,90$ & $p=0,91$ & $p=0,0489$ \\
\hline \multirow[t]{3}{*}{$\mathrm{PI}$} & $(n=32)$ & $\begin{array}{c}1,20[1,05 ; 1,42] \\
P_{3-4}=0,0001\end{array}$ & $1,26[1,12 ; 1,46]$ & $5,03[1,66 ; 7,41]$ \\
\hline & $(n=32)$ & $\begin{array}{c}1,22[0,99 ; 1,45] \\
P_{3-4}=0,0001\end{array}$ & $1,26[1,00 ; 1,48]$ & $1,13[0,66 ; 2,89]$ \\
\hline & р-рівень & $p=0,88$ & $p=0,57$ & $p=0,002$ \\
\hline \multirow[t]{3}{*}{$s / d$} & $(n=32)$ & $\begin{array}{c}2,95[2,60 ; 3,38] \\
P_{3-4}=0,0013\end{array}$ & $2,89[2,54 ; 3,17]$ & $-2,26[-3,63 ;-0,01]$ \\
\hline & $(n=32)$ & $\begin{array}{c}3,08[2,58 ; 3,47] \\
P_{3-4}=0,0001\end{array}$ & $2,95[2,48 ; 3,26]$ & $-5,62[-7,14 ;-4,42]$ \\
\hline & р-рівень & $p=0,76$ & $p=0,91$ & $p=0,0001$ \\
\hline
\end{tabular}


Огляди літератури, оригінальні дослідження, погляд на проблему, випадок з практики, короткі повідомлення чить про покращення еластичних властивостей басейну ВСА. Таким, чином проведена комбінована терапія привела до покращення кровотоку, поліпшення пружноеластичних властивостей артерій і зменшення циркуляторного опору в обох підрупах хворих. Однак, на відміну від показників лінійних швидкостей кровотоку в басейні ЗагСА, показники лінійних швидкостей кровотоку в басейні ВСА достовірно $(p<0,05)$ відрізнялися між підгрупами після проведеної терапії: діаметр ВСА і співвідношення s/d більш значуще знижувалися в підгрупі хворих після терапії з використанням сартанів, Vps, Ved i TAMX більш значуще підвищувалися в підгрупі хворих після терапії з використанням інгібіторів АПФ.

Водночас показники лінійних швидкостей та індексів периферійного опору в басейні зовнішньої сонної артерії (ЗовнСА) у хворих на ГХ ІІ стадії 3 надлишковою вагою (табл. 5), які також достовірно ( $>0,05)$ не відрізнялись у обох підгрупах до лікування, достовірно покращилися після 120 днів лікування. Діаметр ЗовнСА достовірно $(p<0,05)$ зменшився на $(4,04 \pm 0,30) \%$ і $(3,50 \pm 0,54) \%$ в обох підгрупах відповідно. Рівні Vps, Ved і TAMX достовірно $(p<0,05)$ підвищилися: Vps на $(6,33 \pm 0,36) \%$ i $(6,39 \pm 0,45) \%$, Ved на $(9,94 \pm 0,37) \%$ і $(9,56 \pm 0,59) \%$, TAMX на $(3,06 \pm 0,30) \%$ і $(2,66 \pm 0,33) \%$ у обох підгрупах відповідно. RI достовірно $(p<0,05)$ знизився на $(1,14 \pm 0,22) \%$ і $(6,26 \pm 0,20) \%$, а РІ достовірно ( $<<0,05)$ підвищився на $(2,33 \pm 0,32) \%$ i $(2,73 \pm 0,38) \%$

Таблиця 5. Показники лінійних швидкостей кровотоку в басейні зовнішньої сонної артерії у хворих на ГХ II стадії з надлишковою вагою при комбінованій терапії (Me [25; 75], n=64)

\begin{tabular}{|c|c|c|c|c|}
\hline $\begin{array}{c}\text { Показник, одиниця } \\
\text { вимірювання }\end{array}$ & $\begin{array}{l}\text { Підгрупи } \\
\text { терапії }\end{array}$ & До лікування & Через 120 днів & $\Delta \%$ \\
\hline \multirow[t]{3}{*}{$\mathrm{D}, \mathrm{MM}$} & $(n=32)$ & $\begin{array}{c}3,80[4,25 ; 4,65] \\
P_{3-4}=0,0001\end{array}$ & $3,60[3,38 ; 3,88]^{*}$ & $-4,11[-5,27 ;-2,94]^{*}$ \\
\hline & $(n=32)$ & $\begin{array}{c}3,90[3,68 ; 4,23] \\
p_{3-4}=0,0001\end{array}$ & $3,75[3,53 ; 4,10]$ & $-2,88[-4,57 ;-1,43]$ \\
\hline & р-рівень & $p=0,24$ & $p=0,14$ & $p=0,91$ \\
\hline \multirow[t]{3}{*}{ Vps, cm/c } & $(n=32)$ & $\begin{array}{c}62,40[54,10 ; 74,80] \\
P_{3-4}=0,0001\end{array}$ & $65,95[57,70 ; 82,20]^{*}$ & $6,37[5,18 ; 7,44]$ \\
\hline & $(n=32)$ & $\begin{array}{c}64,83[54,98 ; 80,78] \\
\mathrm{P}_{3-4}=0,0001\end{array}$ & $69,30[60,70 ; 85,20]$ & $6,09[5,08 ; 7,13]^{*}$ \\
\hline & р-рівень & $p=0,77$ & $p=0,70$ & $p=0,42$ \\
\hline \multirow[t]{3}{*}{ Ved, cm/c } & $(n=32)$ & $\begin{array}{c}13,30[9,98 ; 17,50] \\
p_{3-4}=0,0001\end{array}$ & $14,75[11,25 ; 19,35]$ & $9,78[8,92 ; 10,80]^{*}$ \\
\hline & $(n=32)$ & $\begin{array}{c}16,65[12,38 ; 17,73] \\
\mathrm{P}_{3-4}=0,0001\end{array}$ & $17,80[14,25 ; 20,00]^{*}$ & $8,29[7,00 ; 11,93]^{*}$ \\
\hline & р-рівень & $p=0,15$ & $p=0,16$ & $p=0,91$ \\
\hline \multirow[t]{3}{*}{ TAMX, cM/c } & $(n=32)$ & $\begin{array}{c}23,73[20,05 ; 26,30] \\
P_{3-4}=0,0001\end{array}$ & $24,15[20,65 ; 27,15]^{*}$ & $2,86[2,02 ; 4,33]^{*}$ \\
\hline & $(n=32)$ & $\begin{array}{c}26,68[21,25 ; 33,65] \\
P_{3-4}=0,0001\end{array}$ & $27,05[21,80 ; 34,45]$ & $2,21[1,73 ; 3,13]^{*}$ \\
\hline & р-рівень & $p=0,08$ & $p=0,10$ & $p=0,16$ \\
\hline \multirow[t]{3}{*}{ RI } & $(n=32)$ & $\begin{array}{c}0,80[0,77 ; 0,83]^{*} \\
\mathrm{P}_{3-4}=0,0001\end{array}$ & $0,79[0,76 ; 0,82]$ & $-1,14[-1,47 ;-0,36]$ \\
\hline & $(n=32)$ & $\begin{array}{c}0,78[0,72 ; 0,81]^{*} \\
\mathrm{P}_{3-4}=0,0001\end{array}$ & $0,74[0,68 ; 0,77]^{*}$ & $-6,08[-6,82-5,26]$ \\
\hline & р-рівень & $p=0,13$ & $p=0,001$ & $p=0,001$ \\
\hline \multirow[t]{3}{*}{$\mathrm{PI}$} & $(n=32)$ & $\begin{array}{c}2,17[1,99 ; 2,42]^{*} \\
p_{3-4}=0,0001\end{array}$ & $2,22[2,00 ; 2,46]^{*}$ & $2,32[0,97 ; 3,37]^{*}$ \\
\hline & $(n=32)$ & $\begin{array}{c}1,93[1,60 ; 2,27]^{*} \\
\mathrm{P}_{3-4}=0,0001\end{array}$ & $1,98[1,71 ; 2,34]^{*}$ & $2,39[1,14 ; 4,01]^{*}$ \\
\hline & р-рівень & $p=0,06$ & $p=0,15$ & $p=0,39$ \\
\hline \multirow[t]{3}{*}{$s / d$} & $(n=32)$ & $\begin{array}{c}5,12[4,28 ; 6,12]^{*} \\
\mathrm{P}_{3-4}=0,0001\end{array}$ & $5,07[4,08 ; 5,79]^{*}$ & $-3,18[-6,44 ;-1,54]$ \\
\hline & $(n=32)$ & $\begin{array}{c}4,59[3,40 ; 5,28]^{*} \\
\mathrm{P}_{3-4}=0,0001\end{array}$ & $4,43[3,29 ; 5,03]^{*}$ & $-2,61[-4,96 ;-1,16]$ \\
\hline & р-рівень & $p=0,13$ & $p=0,15$ & $p=0,91$ \\
\hline
\end{tabular}


Огляди літератури, оригінальні дослідження, погляд на проблему, випадок з практики, короткі повідомлення в обох підгрупах відповідно. В той же час спосте-

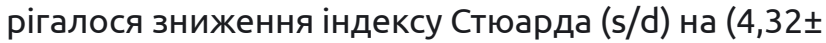
$0,63) \%$ і $(3,41 \pm 0,49)$ \% у обох підгрупах відповідно. Достовірних відмінностей між показниками в підгрупах після проведеної комбінованої терапії не спостерігалося, за винятком показника RI, який достовірно $(p<0,05)$ більш значуще знижувався в підгрупі хворих, у яких застосовували комбіновану терапію з використанням сартанів.

Таким чином, проведена комбінована терапія з використанням як сартанів, так і інгібіторів АПФ, достовірно сприяла поліпшенню кровотоку в басейнах ЗагСА, ВСА і ЗовнСА, що проявлялося в зниженні рівня периферійного опору, поліпшенні пружноеластичних властивостей артерій, зменшенні циркуляторного опору, вазоспазму і тонусу судин, а також у структурному ремоделюванні судин головного мозку (зниженні діаметра судин під впливом комбінованої терапії).

Показники лінійних швидкостей та індексів периферійного опору середньої мозкової артерії (СМА) у хворих на ГX II стадії з надлишковою вагою (табл. 6) достовірно не відрізнялися між підгрупами до лікування. Показники Vps, Ved i TAMX достовірно $(p<0,05)$ підвищились в обох підгрупах після проведеної комбінованої терапії у порівнянні з показниками до лікування: Vps на $(12,86 \pm 0,57) \%$ і $(17,90 \pm 1,34) \%$, Ved на $(19,07 \pm 0,77) \%$ і $(23,79 \pm 1,46) \%$, TAMX на $(1,85 \pm 0,32) \%$ і $(5,81 \pm 1,42) \%$ в обох підгрупах відповідно. Індекс резистивності (RI) достовірно $(p<0,05)$ знизився в двох підгрупах на $(7,85 \pm$ $0,35) \%$ i $(6,12 \pm 0,33)$ \% відповідно, а індекс пульсації (PI) достовірно $(p<0,05)$ підвищився в обох підгрупах на $(5,73 \pm 0,76)$ \% і $(8,02 \pm 1,10)$ \% відповідно. Співвідношення s/d достовірно $(p<0,05)$ знизилось в першій підгрупі на $(8,07 \pm 1,07)$ \% і в другій підгрупі на $(8,19 \pm 1,23) \%$, що свідчить про покращення еластичних властивостей СМА в результаті проведеної терапії. При порівнянні показників у підгрупах

Таблиця 6. Показники лінійних швидкостей кровотоку в басейні середньої мозкової артерії у хворих на ГХ II стадії з надлишковою вагою при комбінованій терапії (Me [25; 75], n=64)

\begin{tabular}{|c|c|c|c|c|}
\hline $\begin{array}{c}\text { Показник, одиниця } \\
\text { вимірювання }\end{array}$ & $\begin{array}{l}\text { Підгрупи } \\
\text { терапії }\end{array}$ & До лікування & Через 120 днів & $\Delta \%$ \\
\hline \multirow[t]{3}{*}{$\mathrm{Vps}, \mathrm{cm} / \mathrm{c}$} & $(n=32)$ & $\begin{array}{c}94,15[77,95 ; 98,50] \\
P_{3-4}=0,0001\end{array}$ & $109,40[91,50 ; 112,60]^{*}$ & $13,33[10,44 ; 15,49]$ \\
\hline & $(n=32)$ & $\begin{array}{c}88,40[79,28 ; 99,75] \\
P_{3-4}=0,0001\end{array}$ & $107,40[98,65 ; 118,55]^{*}$ & $18,10[15,33 ; 22,03]$ \\
\hline & P-рівень & $p=0,90$ & $p=0,32$ & $p=0,0004$ \\
\hline \multirow[t]{3}{*}{ Ved } & $(n=32)$ & $\begin{array}{c}36,88[28,73 ; 44,80] \\
P_{3-4}=0,0001\end{array}$ & $44,38[35,83 ; 55,33]^{*}$ & $18,70[17,41 ; 19,91]$ \\
\hline & $(n=32)$ & $\begin{array}{c}37,33[31,78 ; 42,13] \\
p_{3-4}=0,0001\end{array}$ & $50,30[45,50 ; 53,70]^{* *}$ & $23,97[20,13 ; 29,40]$ \\
\hline & р-рівень & $p=0,79$ & $p=0,21$ & $p=0,00035$ \\
\hline \multirow[t]{3}{*}{ TAMX } & $(n=32)$ & $\begin{array}{c}54,75[44,75 ; 62,33] \\
P_{3-4}=0,0001\end{array}$ & $55,50[45,55 ; 63,30]^{*}$ & $1,79[1,11 ; 2,82]$ \\
\hline & $(n=32)$ & $\begin{array}{c}53,33[48,20 ; 60,90] \\
P_{3-4}=0,00024\end{array}$ & $56,50[49,75 ; 65,25]$ & $2,61[0,39 ; 7,11]$ \\
\hline & P-рівень & $p=0,76$ & $p=0,66$ & $p=0,91$ \\
\hline \multirow[t]{3}{*}{ RI } & $(n=32)$ & $\begin{array}{c}0,59[0,52 ; 0,64] \\
P_{3-4}=0,0001\end{array}$ & $0,53[0,48 ; 0,58]$ & $-7,86[-9,35 ;-6,25]$ \\
\hline & $(n=32)$ & $\begin{array}{c}0,59[0,55 ; 0,64] \\
P_{3-4}=0,0001\end{array}$ & $0,55[0,52 ; 0,60]$ & $-5,47[-7,81 ;-4,86]$ \\
\hline & P-рівень & $p=0,52$ & $p=0,23$ & $p=0,01$ \\
\hline \multirow[t]{3}{*}{$\mathrm{PI}$} & $(n=32)$ & $\begin{array}{c}0,96[0,78 ; 1,17] \\
P_{3-4}=0,0001\end{array}$ & $1,04[0,85 ; 1,25]$ & $4,95[2,02 ; 9,23]$ \\
\hline & $(n=32)$ & $\begin{array}{c}0,94[0,83 ; 1,13] \\
P_{3-4}=0,0001\end{array}$ & $1,02[0,89 ; 1,24]$ & $6,93[2,04 ; 14,00]$ \\
\hline & р-рівень & $p=0,86$ & $p=0,64$ & $p=0,91$ \\
\hline \multirow[t]{3}{*}{$s / d$} & $(n=32)$ & $\begin{array}{c}2,41[2,10 ; 2,73] \\
P_{3-4}=0,0001\end{array}$ & $2,27[1,93 ; 2,54]$ & $-7,30[-11,55 ;-3,87]$ \\
\hline & $(n=32)$ & $\begin{array}{c}2,39[2,12 ; 2,78] \\
p_{3-4}=0,0001\end{array}$ & $2,23[2,01 ; 2,50]$ & $-7,67[-11,58 ;-1,73]$ \\
\hline & P-рівень & $p=0,98$ & $p=0,86$ & $p=0,39$ \\
\hline
\end{tabular}


Огляди літератури, оригінальні дослідження, погляд на проблему, випадок з практики, короткі повідомлення після 120 днів терапії відзначається достовірно ( $<<0,05)$ більш значуще збільшення показників Vps i Ved в підгрупі хворих, яких лікували з використанням сартанів, а також достовірно $(p<0,05)$ більш значуще зниження індексу резистивності в підгрупі хворих, яких лікували з використанням інгібіторів АПФ. Беручи до уваги, що СМА являє собою найбільшу гілку внутрішньої сонної артерії, а ії̈ коркові гілки кровопостачають всю конвекситальну поверхню півкуль головного мозку та потиличні частки, і вона забезпечує метаболічні потреби основних аналізаторних систем кори головного мозку - рухової, пропріоцептивної, слухової та вестибулярної, покращення кровотоку в басейні саме цієї артерії свідчить про значне зниження серцево-судинного ризику, зокрема ризику виникнення інсульту.

Показники лінійних швидкостей та індексів периферійного опору в басейні хребцевої артерії (XА) у хворих на ГX II стадії з надлишковою вагою (табл. 7) достовірно не відрізнялися у обох підгрупах до лікування, за винятком показників індексу пульсації і співвідношення s/d, що, на відміну від відсутності достовірної різниці між цими показниками в каротидному басейні, можливо, обумовлено індивідуальними особливостями обстежених (наявністю супутнього захворювання - остеохондрозу шийного відділу хребта, який призводить до звуження діаметра ХА та зниження швидкісних характеристик кровотоку). Після 120 днів лікування

Таблиця 7. Показники лінійних швидкостей кровотоку в басейні хребцевої артерії (V2) у хворих на ГX II стадії з надлишковою вагою при комбінованій терапії (Me [25; 75], n=64)

\begin{tabular}{|c|c|c|c|c|}
\hline $\begin{array}{c}\text { Показник, одиниця } \\
\text { вимірювання }\end{array}$ & $\begin{array}{c}\text { Підгрупи } \\
\text { терапії }\end{array}$ & До лікування & Через 120 днів & $\Delta \%$ \\
\hline \multirow[t]{3}{*}{$\mathrm{d}$} & $(n=32)$ & $\begin{array}{c}3,23[2,90 ; 3,45] \\
p_{3-4}=0,0001\end{array}$ & $3,30[3,03 ; 3,50]^{*}$ & $1,43[0,93 ; 3,18]^{*}$ \\
\hline & $(n=32)$ & $\begin{array}{c}3,15[2,95 ; 3,35] \\
p_{3-4}=0,0001\end{array}$ & $3,60[3,30 ; 3,70]^{*}$ & $11,11[10,61 ; 12,16]$ \\
\hline & р-рівень & $p=0,99$ & $p=0,0004$ & $p=0,0001$ \\
\hline \multirow[t]{3}{*}{ Vps, cM $\backslash c$} & $(n=32)$ & $\begin{array}{c}43,85[35,18 ; 50,35] \\
P_{3-4}=0,0001\end{array}$ & $48,90[40,00 ; 60,00]^{*}$ & $16,17[14,02 ; 17,35]$ \\
\hline & $(n=32)$ & $\begin{array}{c}43,33[37,10 ; 52,08] \\
P_{3-4}=0,0001\end{array}$ & $49,70[42,90 ; 59,60]^{*}$ & $12,38[10,29 ; 15,53]$ \\
\hline & р-рівень & $p=0,57$ & $p=0,77$ & $p=0,002$ \\
\hline \multirow[t]{3}{*}{ Ved } & $(n=32)$ & $\begin{array}{c}14,58[13,23 ; 18,88] \\
P_{3-4}=0,0001\end{array}$ & $19,30[17,01 ; 23,10]^{*}$ & $23,23[19,00 ; 25,29]$ \\
\hline & $(n=32)$ & $\begin{array}{c}14,73[12,65 ; 16,55] \\
P_{3-4}=0,0001\end{array}$ & $18,40[16,40 ; 19,85]^{*}$ & $16,59[13,70 ; 23,21]$ \\
\hline & р-рівень & $p=0,31$ & $p=0,12$ & $p=0,01$ \\
\hline \multirow[t]{3}{*}{ TAMX } & $(n=32)$ & $\begin{array}{c}26,10[21,55 ; 27,75] \\
P_{3-4}=0,0001\end{array}$ & $27,80[22,90 ; 30,35]^{*}$ & $6,42[3,18 ; 8,20]^{*}$ \\
\hline & $(n=31)$ & $\begin{array}{c}22,85[21,30 ; 24,93] \\
P_{3-4}=0,0001\end{array}$ & $23,50[22,75 ; 26,85]^{*}$ & $5,30[3,55 ; 6,90]^{*}$ \\
\hline & р-рівень & $p=0,17$ & $p=0,097$ & $p=0,91$ \\
\hline \multirow[t]{3}{*}{$\mathrm{RI}$} & $(n=32)$ & $\begin{array}{c}0,64[0,59 ; 0,71] \\
p_{3-4}=0,0001\end{array}$ & $0,60[0,55 ; 0,66]$ & $-7,75[-10,05 ;-6,40]^{*}$ \\
\hline & $(n=32)$ & $\begin{array}{c}0,66[0,63 ; 0,71] \\
p_{3-4}=0,0001\end{array}$ & $0,61[0,58 ; 0,66]$ & $-7,76[-8,27 ;-6,62]^{*}$ \\
\hline & р-рівень & $p=0,66$ & $p=0,65$ & $p=0,40$ \\
\hline \multirow[t]{3}{*}{$\mathrm{PI}$} & $(n=32)$ & $\begin{array}{c}1,02[0,86 ; 1,30] \\
p_{3-4}=0,0001\end{array}$ & $1,12[0,88 ; 1,40]^{*}$ & $3,74[2,17 ; 7,80]^{*}$ \\
\hline & $(n=32)$ & $\begin{array}{c}1,28[1,11 ; 1,43] \\
P_{3-4}=0,0001\end{array}$ & $1,32[1,17 ; 1,56]$ & $2,94[0,79 ; 7,47]$ \\
\hline & р-рівень & $p=0,0026$ & $p=0,0032$ & $p=0,39$ \\
\hline \multirow[t]{3}{*}{$s / d$} & $(n=32)$ & $\begin{array}{c}2,17[2,30 ; 3,09] \\
p_{3-4}=0,0001\end{array}$ & $2,45[2,09 ; 2,88]^{*}$ & $-8,52[-11,84 ;-4,65] *$ \\
\hline & $(n=32)$ & $\begin{array}{c}2,91[2,72 ; 3,62] \\
P_{3-4}=0,0001\end{array}$ & $2,81[2,55 ; 3,09]$ & $-6,84[-12,29 ;-1,42]$ \\
\hline & p-рівень & $p=0,029$ & $p=0,0099$ & $p=0,91$ \\
\hline
\end{tabular}


Огляди літератури, оригінальні дослідження, погляд на діаметр XА достовірно $(p<0,05)$ знизився на $(2,41 \pm 0,36) \%$ у першій підгрупі і на $(11,44 \pm 0,26) \%$ у другій підгрупі. Показники Vps, Ved i TAMX XA, як i басейнах інших досліджених артерій, достовірно ( $<<0,05)$ підвищились в обох підгрупах після проведеної комбінованої терапії у порівнянні з показниками до лікування: Vps на $(15,35 \pm 0,63) \%$ і $(12,40 \pm$ $0,88) \%$, Ved на $(21,97 \pm 0,91) \%$ і $(18,09 \pm 1,30) \%$, TAMX на $(5,98 \pm 0,58)$ \% і $(5,31 \pm 0,46) \%$ в обох підгрупах відповідно. Індекс резистивності (RI) після проведеної комбінованої терапії достовірно $(p<0,05)$ знизився на $(7,94 \pm 0,49) \%$ і $(7,63 \pm 0,19) \%$, а індекс пульсації достовірно $(p<0,05)$ збільшився на $(7,30 \pm 2,04) \%$ i $(4,30 \pm 0,77)$ \% в обох підгрупах відповідно. Систоло-діастолічне співвідношення (s/d) достовірно $(p<0,05)$ знизилося в обох підгрупахна $(8,45 \pm 1,03) \%$ і $(7,65 \pm 1,32)$ \% відповідно. Необхідно також відмітити достовірно ( $<20,05)$ більш значуще збільшення діаметра ХА в підгрупі хворих, в яких застосовувалася терапія з включенням сартанів, а також досто- обему, випадок з практики, короткі повідомлення вірно ( $<<0,05)$ більш значуще збільшення показників Vps i Ved у підгрупі хворих, в яких застосовувалася терапія з включенням інгібіторів АПФ.

Висновки: 1. У хворих на гіпертонічну хворобу II стадії з надлишковою вагою проведена 120-денна антигіпертензивна терапія з використанням інгібіторів АПФ, сартанів, антагоністів кальцію у поєднанні зі статинами привела до достовірного посилення скоротливої функції лівого шлуночка, зворотного його ремоделювання, достовірного покращення процесів релаксації лівого шлуночка.

2. На фоні проведеної антигіпертензивної та протиліпідемічної терапії достовірно зменшився діаметр мозкових артерій (загальної сонної, внутрішньої сонної, зовнішньої сонної, середньомозкової та хребтової), разом з цим зменшувалася їх товщина та підвищувалася еластичність їх стінки й градієнт кровотоку, що проявлялось у зниженні периферійного та циркулярного опору і покращенні мозкового кровообігу.

\section{ЛІТЕРАТУРА}

1. Поведінкові детермінанти здоров'я (результати національного репрезентативного дослідження «ндекс здоров'я. Україна») / Т. Степурко, Т. Семигіна, Ю. Барська, В. Тимошевська // Вісник АПСВТ. - 2019. - № 1. C. $102-124$

2. Висцеральное ожирение как глобальный фактор сердечно-сосудистого риска / Г. А. Чумакова, Т. Ю. Кузнецова, М. А. Дружилов, Н. Г. Веселовская // Российский кардиологический журнал. - 2018. - № 23 (5). - С. 7-14. DOI: http://doi.org/10.15829/1560-4071-2018-5-7-14.

3. Association of changes in abdominal fat quantity and quality with incident cardiovascular disease risk factors / J. Lee, A. Pedley, U. Hoffmann [et al.] // J. Am. Coll. Cardiol. - 2016. - Vol. 68, Issue 14. - P. 1509-1521. DOI: https://doi.org/10.1016/j.jacc.2016.06.067.

4. Obesity phenotypes and their paradoxical association with cardiovascular diseases / A. Vecchie, F. Dallegri, F . Carbone [et al.] // Eur. J. Intern. Med. - 2018. - Vol. 48. P. 6-17. DOI: https://doi.org/10.1016/j.ejim.2017.10.020.

5. Position paper of the European Society of Cardiology-working group of coronary pathophysiology and microcirculation: obesity and heart disease / L. Badimon, R. Bugiardini, E. Cenko [et al.] // Eur. Heart J. - 2017. - Vol. 38. P. 1951-1958. DOI: https://doi.org/10.1093/eurheartj/ehx181.

6. Факторы риска ишемической болезни сердца у 27425 амбулаторных пациентов / А. С. Галявич, Р. Н. Хайруллин, Л. В. Балеева [и др.] // Российский кардиологический журнал. - 2019. - № 66. - С. 23-26. DOI: http://doi.org/10.15829/1560-4071-2019-6-23-26.

7. Механизмы и принципы коррекции метаболического синдрома (обзор литературы) / Л. Г. Агасаров, Т. В. Апханова, О. Ю. Киргизова, В. К. Фролков // Вестник новых медицинских технологий. - 2019. - № 3. - С. 40-47. DOI: https://doi.org/10.24411/2075-4094-2019-16385.

8. Отт А. В. Эпикардиальное ожирение как один из основных критериев метаболически тучного фенотипа ожирения и предикторов субклинического атеросклероза /
А. В. Отт, Г. А. Чумакова // Комплексные проблемы сердечно-сосудистых заболеваний. - 2018. - № 7 (1). - С. 21-28. DOI: https://doi.org/10.17802/306-1278-2018-7-1-21-28.

9. Особенности полиморбидности у больных артериальной гипертензией / Е. В. Севостьянова, Ю. А. Николаев, И. М. Митрофанов, В. Я. Поляков // Артериальная гипертензия. - 2019. - № 25 (2). - С. 200-208. DOI: https://doi.org/10.18705/1607-419X-2019-25-2-200-208.

10. American Association of Clinical Endocrinologists and American College of Endocrinology guidelines for management of dyslipidemia and prevention of cardiovascular disease / P. S. Jellinger, Y. Handelsman, P. Rosenblit [et al.] // Endocrine Practice. - 2017. - Vol. 23, Suppl. 2. - P. 1-87. DOI: https://doi.org/10.4158/EP171764.APPGL.

11. "Double-Trouble" Atherogenic Lipid Profile In Overweight/Obese Hypertensive Patients Phenotyped By 24-Hour Ambulatory Blood Pressure Monitoring / F. Spannella, F. Giulietti, C. Di Pentima [et al.] // Atherosklerosis. 2019. - Vol. 287. - P. e191.

12. Targeting white, brown and perivascular adipose tissue in atherosclerosis development / A. D. van Dam, M. R. Boon, J. F. P. Berbée [et al.] // European Journal of Pharmacology. - 2017. - Vol. 816. - P. 82-92. DOI: https://doi.org/10.1016/j.ejphar.2017.03.051.

13. Киреев Т. Р. Комплексная оценка состояния головного мозга у пациентов с артериальной гипертонией пожилого возраста / Т. Р. Киреев // Практическая медицина. - 2018. - Т. 16, № 6. - С. 225-227.

14. Оценка состояния сосудов у пациентов с артериальной гипертензией / Н. Ж. Мирзагалиева, Р. А. Арингазина, А. Р. Астраханов, М. А. Отесин // Международный журнал сердца и сосудистых заболеваний. - 2019. - Т. 7, № 21. - С. 20-25.

15. Роль магнитно-резонансной томографии в выявлении ранних признаков поражения головного мозга при артериальной гипертензии / О. Д. Остроумова, 
Огляди літератури, оригінальні дослідження, погляд на проблему, випадок з практики, короткі повідомлення

Т. М. Остроумова, В. А. Перепелов [и др.]//Эффективная фармакотерапия. - 2017. - № 33. - С. 44-50.

16. Лындина М. Л. Сосудистые нарушения при ожирении: факторы риска и клинические особенности / М. Л. Лындина, А. Н. Шишкин // Juvenis scientia. Medicine. 2018. - № 2. - С. 9-13.

17. Роль ультразвуковой визуализации субклинического атеросклероза сонных артерий в прогнозировании сердечно-сосудистого риска в рамках первичной кардиоваскулярной профилактики / А. Е. Головина, Н. О. Катамадзе, Е. В. Бондарева [и др.] // Атеросклероз и дислипидемии. - 2017. - № 1. - С. 5-16.

18. ESC/ESH Guidelines for the management of arterial hypertension / B. Williams, G. Mancia, W. Spiering [et al.] // Eur. Heart J. - 2018. - Vol. 39, Issue 33. - P. 30213104. DOI: https://doi.org/10.1093/eurheartj/ehy339.

\section{REFERENCES}

1. Stepurko, T., Semyhina, T., Barska, Yu., \& Tymoshevska, V. (2019). Povedinkovi determinanty zdorovia (rezultaty natsionalnoho reprezentatyvnoho doslidzhennia "Indeks zdorovia. Ukraina") [Behavioral determinants of health (results of the national representative survey "health index. Ukraine")]. Visnyk APSVT - ATSVT Bulletin, 1, 102-124 [in Ukrainian].

2. Chumakova, G.A., Kuznetsova, T.Yu., Druzhilov, M.A., \& Veselovskaya, N.G. (2018). Vistseralnoye ozhireniye kak globalnyy faktor serdechno-sosudistogo riska [Visceral obesity as a global factor in cardiovascular risk]. Rossiyskiy kardiologicheskiy zhurnal - Russian Journal of Cardiology, 23 (5), 7-14. DOI: http://doi.org/10.15829/1560-4071-2018-5-7-14.

3. Lee, J.J., Pedley, A., Hoffmann, U., Massaro, J. M., \& Fox, C.S. (2016). Association of changes in abdominal fat quantity and quality with incident cardiovascular disease risk factors. J. Am. Coll. Cardiol., 68, 14, 1509-1521. DOI: https://doi.org/10.1016/j.jacc.2016.06.067.

4. Vecchié, A., Dallegri, F., Carbone, F., Bonaventura, A., Liberale, L., Portincasa, P., Frühbeck, G., \& Montecucco, F. (2018). Obesity phenotypes and their paradoxical association with cardiovascular diseases. Eur. J. Intern. Med., 48, 6-17. DOI: https://doi.org/10.1016/j.ejim.2017.10.020.

5. Badimon, L., Bugiardini, R., Cenko, E., Cubedo, J., Dorobantu, M., Duncker, D.J., ..., \& Koller, A. (2017). Position рарег of the European Society of Cardiology-working group of coronary pathophysiology and microcirculation: obesity and heart disease. Eur. Heart J., 38, 1951-1958. DOI: https:// doi.org/10.1093/eurheartj/ehx181.

6. Galyavich, A.S., Khairullin, R.N., Baleeva, L.V., Sluiter, P., Akimova, S.V., Galimzyanov, A.F., ..., \& Terpstra, P. (2019). Faktory riska ishemicheskoy bolezni serdtsa u 27425 ambulatornykh patsiyentov [Risk factors of coronary artery disease in 27425 outpatients]. Rossiyskiy kardiologicheskiy zhurnal - Russian Journal of Cardiology, 66, 23-26 [in Russian]. DOI: http://doi.org/10.15829/1560-4071-2019-6-23-26.

7. Agasarov, L.G., Apkhanova, T.V., Kirgizova, O.Yu., \& Frolkov, V.K. (2019). Mekhanizmy i printsipy korrektsii metabolicheskogo sindroma (obzor literatury) [Mechanisms and principles of metabolic syndrome correction (literature review)]. Vestnik novykh meditsinskikh tekhnologiy-Bulletin of New Medical Technologies, 3, 40-47. DOI: https://doi. org/10.24411/2075-4094-2019-16385 [in Russian].
19. The role of vascular biomarkers for primary and secondary prevention. A position paper from the European Society of Cardiology Working Group on peripheral circulation: endorsed by the Association for Research into Arterial Structure and Physiology (ARTERY) Society / C. Vlachopoulos, P. Xaplanteris, V. Aboyans [et al.] // Atherosclerosis. 2015. - Vol. 241, Issue 2. - P. 507-532. DOI: https://doi. org/10.1016/j.atherosclerosis.2015.05.007.

20. Пропозиції щодо стандартизації ультразвукового дослідження судин шиї та голови / М. В. Глоба, В. Й. Калашніков, Г. В. Лінська // Український нейрохірургічний журнал. - 2017. - № 1. - С. 40-45.

21. Ультразвуковое исследование сердца и сосудов / под ред. О. Ю. Атькова. 2-е изд., доп. и расшир. М. : ЭКсмо, 2015. -456 с.

8. Ott, A.V., \& Chumakova, G.A. (2018). Epikardialnoye ozhireniye kak odin iz osnovnykh kriteriyev metabolicheski tuchnogo fenotipa ozhireniya i prediktorov subklinicheskogo ateroskleroza [Epicardial obesity as one of the basic criteria for metabolically unhealthy obesity phenotype and the predictor of subclinical atherosclerosis]. Kompleksnyye problemy serdechno-sosudistykh zabolevaniy - Complex Issues of Cardiovascular Diseases, 7 (1), 21-28. DOI: https://doi. org/10.17802/2306-1278-2018-7-1-21-28 [in Russian].

9. Sevostyanova, Ye.V., Nikolayev, Yu.A., Mitrofanov, I.M., \& Polyakov, V.Ya. (2019). Osobennosti polimorbidnosti u bolnykh arterialnoy gipertenziyey [Polymorbidity in hypertensive patients]. Arterialnaya gipertenziya - Arterial hypertension, 25 (2), 200-208. DOI: https://doi.org/10.18705/ 1607-419X-2019-25-2-200-208 [in Russian].

10. Jellinger, P.S., Handelsman, Y., Rosenblit, P.D., Bloomgarden, Z.T., Fonseca, V.A., Garber, A.J., ..., \& Davidson, M. (2017). American Association of Clinical Endocrinologists and American College of Endocrinology guidelines for management of dyslipidemia and prevention of cardiovascular disease. Endocrine Practice, 23, 2, 1-87. DOI: https:// doi.org/10.4158/EP171764.APPGL.

11. Spannella, F., Giulietti, F., Di Pentima, C., Ristori, L., Biondini, S., \& Sarzani, R. (2019). "Double-trouble" atherogenic lipid profile in overweight/obese hypertensive patients phenotyped by 24-hour ambulatory blood pressure monitoring. Atherosklerosis, 287, e191.

12. van Dam, A.D., Boon, M.R., Berbée, J.F.P., Rensen, P.C.N., \& van Harmelen, V. (2017). Targeting white, brown and perivascular adipose tissue in atherosclerosis development. European Journal of Pharmacology, 816, 8292. DOI: https://doi.org/10.1016/j.ejphar.2017.03.051.

13. Kireyev, T.R. (2018). Kompleksnaya otsenka sostoyaniya golovnogo mozga u patsiyentov s arterialnoy gipertoniyey pozhilogo vozrasta [Comprehensive assessment of the brain status in elderly patients with arterial hypertension]. Prakticheskaya meditsina - Practical Medicine, 16, 6, 225-227 [in Russian].

14. Mirzagaliyeva, N.Zh., Aringazina, R.A., Astrakhanov, A.R., \& Otesin, M.A. (2019). Otsenka sostoyaniya sosudov u patsiyentov s arterialnoy gipertenziyey [Vascular condition assessment in patients with arterial hypertension]. Mezhdunarodnyy zhurnal serdtsa i sosudistykh zabo- 
Огляди літератури, оригінальні дослідження, погляд на проблему, випадок з практики, короткі повідомлення levaniy - International Heart and Vascular Disease Journal, 7, 21, 20-25 [in Russian].

15. Ostroumova, O.D., Ostroumova, T.M., Perepelov, V.A., \& Velichko, M.V. (2017). Rol magnitno-rezonansnoy tomografii v vyyavlenii rannikh priznakov porazheniya golovnogo mozga pri arterialnoy gipertenzii [Role of magnetic resonance imaging in detecting early signs of brain damage in arterial hypertension]. Effektivnaya farmakoterapiya - Effective Pharmacotherapy, 33, 44-50 [in Russian].

16. Lindyna, M.L., \& Shishkin, A.N. (2018). Sosudistyye narusheniya pri ozhirenii: faktory riska i klinicheskiye osobennosti [Vascular disorders in obesity: risk factors and clinical features]. Juvenis scientia. Medicine, 2, 9-13.

17. Golovina, A.Ye., Katamadze, N.O., Bondareva, Ye.B., Sayganov, S.A., \& Bershteyn, L.L. (2017). Rol ultrazvukovoy vizualizatsii subklinicheskogo ateroskleroza sonnykh arteriy v prognozirovanii serdechno-sosudistogo riska v ramkakh pervichnoy kardiovaskulyarnoy profilaktiki [The role of ultrasound imaging of subclinical carotid atherosclerosis in predicting of cardiovascular risk in primary prevention of cardiovascular diseases]. Ateroskleroz i dislipidemii - Atherosclerosis and dyslipidemia, 1, 5-16 [in Russian].

18. Williams, B., Mancia, G., Spiering, W., Rosei, E.A.,

Azizi, M., Burnier, M., ..., \& Desormais, I. (2018). ESC/ESH Guidelines for the management of arterial hypertension. Eur. Heart J., 39, 33, 3021-3104. DOI: https://doi.org/10.1093/eurheartj/ehy339.

19. Vlachopoulos, C., Xaplanteris, P., Aboyans, V., Brodmann, M., Cífková, R., Cosentino, F., ..., \& Townsend, R.R. (2015). The role of vascular biomarkers for primary and secondary prevention. A position paper from the European Society of Cardiology Working Group on peripheral circulation: endorsed by the Association for Research into Arterial Structure and Physiology (ARTERY) Society. Atherosclerosis, 241, 2, 507-532. DOI: https://doi.org/10.1016/j.atherosclerosis.2015.05.007.

20. Hloba, M.V., Kalashnikov, V.Y., \& Linska, H.V. (2017). Propozytsii shchodo standartyzatsii ultrazvukovoho doslidzhennia sudyn shyi ta holovy [Ultrasonography of blood vessels of the head and neck: proposals for standardization]. Ukrainskyi neirokhirurhichnyi zhurnal - Ukrainian Neurosurgical Journal, 1, 40-45 [in Ukrainian].

21. Atkov, O.Yu. (Ed.). (2015). Ultrazvukovoye issledovaniye serdtsa i sosudov [Ultrasound examination of the heart and blood vessels]. 2nd ed., suppl. and expanded. Moscow: Eksmo [in Russian].

\title{
ДИНАМИКА ПОКАЗАТЕЛЕЙ СОКРАТИТЕЛЬНОЙ ФУНКЦИИ МИОКАРДА И ЦЕРЕБРАЛЬНОГО КРОВОТОКА У БОЛЬНЫХ С ГИПЕРТОНИЧЕСКОЙ БОЛЕЗНЬЮ И ИЗБЫТОЧНОЙ МАССОЙ ТЕЛА ПОСЛЕ ТЕРАПИИ АНТИГИПЕРТЕНЗИВНЫМИ СРЕДСТВАМИ В СОЧЕТАНИИ СО СТАТИНАМИ
}

\author{
๑Н. И. Петрик, И. М. Фуштей, Г. Я. Солонинка \\ ГУ «Запорожская медицинская академия последипломного образования МОЗ Украины»
}

РЕЗЮМЕ. Целью работы стала оценка динамики систолической, диастолической функции и ремоделирования левого желудочка миокарда, линейных скоростей кровотока в бассейнах общей сонной артерии, внутренней сонной артерии, наружной сонной артерии, средней мозговой артерии, позвоночной артерии (V2) у больных мужского и женского пола с гипертонической болезнью II стадии и избыточной массой тела под влиянием комбинированной терапии антигипертензивными препаратами и розувастатином.

Материал и методы. У 64 пациентов, средний возраст 59.0 [48.0; 63.0] лет, с гипертонической болезнью II стадии и избыточной массой оценивали динамику систолической, диастолической функции и ремоделирования левого желудочка, линейных скоростей кровотока в бассейнах общей сонной артерии, внутренней сонной артерии, внешней сонной артерии, средней мозговой артерии, позвоночной артерии под влиянием комбинированной терапии (фиксированные комбинации антигипертензивных препаратов - экватор (амлодипин 5 мг и лизиноприл 10 мг) и валодип (амлодипин 5 мг и валсартан 80 мг) в течение 120 суток), в которую входит розувастатин 10 мг в сутки.

Результаты. Всем больным было проведено общеклиническое, лабораторное и инструментальное обследование с целью верификации диагноза, определения осложнений и сопутствующей патологии. На фоне лечения наблюдаются улучшение сократимости левого желудочка, его обратное ремоделирование и увеличение мощности систолического выброса. Показатели диастолической функции левого желудочка после проведенного лечения свидетельствуют об улучшении процессов релаксации левого желудочка, его податливости и сократимости левого предсердия на фоне проведенной терапии, об уменьшении гипертрофии левого желудочка и снижении риска сердечно-сосудистых осложнений. Достоверное уменьшение диаметров обследованных мозговых артерий (ОбщСА, ВСА, ВнешнСА СМА и ПА) на фоне проведенной антигипертензивной и противолипидемической терапии свидетельствует о6 обратном структурно-функциональном ремоделировании сосудов головного мозга - уменьшении толщины и повышении эластичности сосудистой стенки.

Выводы. Улучшение эластических свойств СМА в результате проведенной терапии свидетельствует о значительном снижении сердечно-сосудистого риска, в частности риска возникновения инсульта. Таким образом, наблюдается улучшение мозгового кровообращения и трофики головного мозга, что свидетельствует об адекватности и целесообразности подобранной регулярной антигипертензивной и противолипидемической терапии.

КЛЮЧЕВЫЕ СЛОВА: систолическая функция; диастолическая функция; линейные скорости кровотока; гипертоническая болезнь; избыточная масса тела. 


\title{
MYOCARDIAL CONTRACTILE FUNCTION AND CEREBRAL BLOOD FLOW INDICES DYNAMICS IN HYPERTENSIVE OVERWEIGHT PATIENTS AFTER THERAPY BY ANTIHYPERTENSIVES COMBINED WITH STATINS
}

\author{
@N. I. Petrik, I. M. Fushtei, G. J. Solonunka

\section{Zaporizhzhia Medical Academy of Postgraduate Education}

SUMMARY. The aim of the work was to assess the dynamics of systolic, diastolic function and remodeling of the left ventricle of the myocardium, linear blood flow velocities in the basins of the common carotid artery, internal carotid artery, external carotid artery, middle cerebral artery, vertebral artery (V2) in male and female patients with hypertension II stage and overweight under the influence of combination therapy with antihypertensive drugs and rosuvastatin.

Material and Methods. In 64 patients, the average age is 59.0 [48.0; 63.0] years, with stage II hypertension and overweight, the dynamics of systolic, diastolic function and remodeling of the left ventricle, linear blood flow velocities in the basins of the common carotid artery, internal carotid artery, external carotid artery, middle cerebral artery, vertebral artery under the influence of combination therapy were evaluated (fixed combinations of antihypertensive drugs - the equator (amlodipine $5 \mathrm{mg}$ and lisinopril $10 \mathrm{mg}$ ) and valodip (amlodipine $5 \mathrm{mg}$ and valsartan $80 \mathrm{mg}$ ) for 120 days), which includes rosuvastatin $10 \mathrm{mg}$ per day.

Results. All patients underwent a general clinical, laboratory and instrumental examination in order to verify the diagnosis, identify complications and associated pathology. During treatment, an improvement in left ventricular contractility, its reverse remodeling, and an increase in systolic ejection power are observed. Indicators of diastolic function of the left ventricle after treatment indicate an improvement in the processes of relaxation of the left ventricle, its compliance and contractility of the left atrium during therapy, a decrease in left ventricular hypertrophy and a decrease in the risk of cardiovascular complications. A significant decrease in the diameters of the examined cerebral arteries (CommonAAA, ICA, ExternalCMA and PAA) against the background of the antihypertensive and antilipidemic therapy indicates an inverse structural and functional remodeling of the cerebral vessels - a decrease in thickness and increased elasticity of the vascular wall.

Conclusions. The improvement in the elastic properties of SMA as a result of the therapy indicates a significant reduction in cardiovascular risk, in particular, the risk of stroke. Thus, there is an improvement in cerebral circulation and cerebral trophism, which indicates the adequacy and feasibility of selected regular antihypertensive and anti-lipidemic therapy.

KEY WORDS: systolic function; diastolic function; linear blood flow velocities; arterial hypertension; overweight patients.

Отримано 04.02.2020 